\title{
TRANSFORMASI FATWA DEWAN SYARIAH NASIONAL KE DALAM HUKUM POSITIF
}

\author{
Tuti Hasanah \\ Fakultas Syariah dan Ekonomi Islam IAIN Antasari \\ Jl. Jendral Ahmad Yani Km. 4,5 Banjarmasin \\ E-mail: tutihasanahseimhi@gmail.com
}

\begin{abstract}
This study aims to answer questions arising from the Act No. 21 of 2008 concerning Islamic Banking Article 26, paragraph 1, 2 and 3, the position DSN in positive law and fatwa DSN transformation process to become a positive legal products such as PBI. Type of research is a normative legal research with a qualitative approach, through legislation approaches, concepts, and historical. The conclusion of this study include: first, the fatwa has binding legal effect if the fatwa was reinforced with the instruments of the state that have a legitimate tool. Second, Bank Indonesia can not provide sanctions for Islamic banks or Islamic business units that do not follow the fatwa. Therefore, the solution is taken to be a binding fatwa DSN is through transformation into PBI. Transformation process is influenced by the KPS as referrals to the fatwa DSN.
\end{abstract}

Abstrak: Penelitian ini bertujuan untuk menjawab berbagai pertanyaan yang timbul dari Undang-Undang No. 21 Tahun 2008 tentang Perbankan Syariah Pasal 26 ayat 1, 2 dan 3, yakni posisi Fatwa DSN dalam hukum positif dan proses transformasi fatwa DSN hingga menjadi sebuah produk hukum positif berupa PBI. Jenis penelitian yang dilakukan adalah penelitian hukum normatif dengan pendekatan kualitatif, yakni melalui pendekatan undang-undang, konsep, dan historis. Kesimpulan dari penelitian ini antara lain: pertama, fatwa memiliki kekuatan hukum yang mengikat apabila fatwa tersebut diperkuat dengan instrumen-instrumen negara yang mempunyai alat legitimasi. Kedua, Bank Indonesia tidak bisa memberikan sanksi bagi bank syariah atau unit usaha syariah yang tidak mengikuti fatwa. Oleh sebab itu solusi yang ditempuh agar fatwa menjadi mengikat adalah melalui transformasi fatwa DSN ke dalam PBI. Proses transformasi tersebut dipengaruhi oleh KPS sebagai pemberi rekomendasi terhadap fatwa DSN. Kata Kunci: Transformasi, Fatwa Dewan Syariah Nasional, Hukum Positif

\section{Latar Belakang Masalah}

Di Indonesia, fatwa-fatwa hukum Islam dikeluarkan oleh Mejelis Ulama Indonesia (MUI). Pedoman fatwa Majelis Ulama Indonesia ditetapkan dalam Surat Keputusan Nomor: U-596/MUI/X/1997. Kewenangan Majelis Ulama Indonesia adalah memberi fatwa tentang masalah keagamaan yang bersifat umum yang menyangkut umat Islam Indonesia secara nasional dan dalam masalah agama Islam di daerah yang diduga dapat meluas ke daerah lain. ${ }^{1}$

Majelis Ulama Indonesia (MUI) memiliki bagian yang bertugas menumbuh kembangkan penerapan nilai-nilai syariah dalam kegiatan perekonomian pada umumnya dan sektor keuangan pada khususnya, termasuk usaha bank, asuransi

\footnotetext{
1 Jaih Mubaraok, Metodologi Ijtihad Hukum Islam (Yogyakarta: UII Press, 2002), h. 170-171.
}

dan reksadana yakni Dewan Syariah Nasional (DSN). Sampai saat ini (tahun 2016) tercatat fatwa yang telah dikeluarkan oleh DSN adalah sebanyak 107 buah. $^{2}$ Di dalam DSN sendiri memiliki badan independen yang ditempatkan pada perbankan dan lembaga keuangan syariah yang dikenal dengan sebutan Dewan Pengawas Syariah (DPS).

Dalam perkembangan sistem ekonomi di Indonesia muncul gagasan sistem ekonomi Islam atau ekonomi syariah setelah runtuhnya sistem ekonomi kapitalis. Hal ini terlihat dari munculnya Kompilasi Hukum Islam, perundang-undangan yang memuat unsur syariah didalamnya, fatwafatwa Dewan Syariah Nasional, dan Peraturan Bank

\footnotetext{
2 DSN MUI, Fatwa, http://www.dsnmui.or.id/index. php?page $=$ fatwa, diakses pada Februari 2017.
} 
Indonesia. Diantara perundang-undangan tersebut yakni Undang-undang No. 3 tahun 2006 tentang Perubahan Undang-undang No. 7 tentang Peradilan Agama, dan Undang-undang No. 21 tahun 2008 tentang Perbankan Syariah.

Dalam UU Nomor 21 tahun 2008 tentang Perbankan Syariah pasal 26 ayat 1 menyebutkan bahwa kegiatan usaha sebagaimana dimaksud dalam Pasal 19, Pasal 20, dan Pasal 21 dan/atau produk dan jasa syariah, wajib tunduk kepada Prinsip Syariah. Dimana pada ayat selanjutnya, ayat 2 dan 3 menerangkan bahwa Prinsip Syariah sebagaimana dimaksud pada ayat (1) difatwakan oleh Majelis Ulama Indonesia, dan Fatwa sebagaimana dimaksud pada ayat (2) dituangkan dalam Peraturan Bank Indonesia.

Fatwa-fatwa yang berkaitan dengan kegiatan usaha sebagaimana dijelaskan oleh UU Nomor Nomor 21 tahun 2008 tentang Perbankan Syariah oleh MUI dikeluarkan oleh Dewan Syariah Nasional yang memiliki kewenangan menangani segala urusan yang berkaitan dengan fatwa atas jenisjenis kegiatan keuangan, fatwa atas produk dan jasa keuangan. ${ }^{3}$ Selain itu DSN juga berwenang mengawasi penerapan fatwa yang telah dikeluarkan yang kemudian fatwa-fatwa tersebut dituangkan ke dalam Peraturan Bank Indonesia.

Dalam perkembangan selanjutnya, guna menyusun Peraturan Bank Indonesia sebagaimana dimaksud pada pasal 26 ayat 3 UU Nomor 21 tahun 2008 tentang Perbankan Syariah, maka Bank Indonesia membuat sebuah Komite Perbankan Syariah yang tertuang dalam Peraturan Bank Indonesia, Nomor 10/32/PBI/2008 tentang Komite Perbankan Syariah dimana Komite tersebut berfungsi melakukan penafsiran dan pemaknaan fatwa di bidang perbankan syariah. Selain itu Komite ini bertugas memberikan rekomendasi kepada Bank Indonesia terhadap fatwa-fatwa yang dikeluarkan oleh Dewan Syariah Nasional.

Dari ketentuan tersebut menimbulkan pertanyaan ketika melihat fungsi dan tugas antara Dewan Syariah Nasional Indonesia (DSN) dan Komite Perbankan Syariah (KPS). Bagaimana sebenarnya posisi fatwa DSN di dalam hukum nasional sehingga Fatwa DSN tersebut harus dituangkan kembali ke dalam Peraturan Bank Indonesia melalui penafsiran KPS? Bagaimana

\footnotetext{
3 Berdasarkan Surat Keputusan Dewan Pimpinan MUI tentang Pembentukan Dewan Syariah Nasional (DSN) No. Kep-754/MUI/II/1999.
}

proses transformasi yang harus dilalui agar Fatwa DSN dapat menjadi hukum positif di Indonesia? Untuk menjawab segala pertanyaan dan permasalahan tersebut, maka penulis akan mencoba menjawabnya dalam tulisan ini.

\section{METODE PENELITIAN}

\section{a. Jenis dan Pendekatan yang Digunakan}

Jenis penelitian yang dilakukan adalah penelitian hukum normatif atau penelitian literatur (librarry research). Metode penelitian hukum normatif adalah metode atau cara yang dipergunakan di dalam penelitian hukum yang dilakukan dengan cara meneliti bahan pustaka yang ada.4 Selain itu, penelitian hukum normatif ini menggunakan pendekatan kualitatif.5

\section{b. Desain Penelitian}

Ada empat tahapan pokok dalam penelitian Transformasi fatwa Dewan Syariah Nasional ke dalam Hukum Positif, yaitu: Tahapan Orientasi, Tahap Eksplorasi, Tahap Pengecekan, dan terakhir peneliti akan melakukan Tahap Penyusunan.

\section{c. Bahan Hukum ${ }^{6}$}

Kegiatan penelitian ini dipusatkan pada kajian terhadap bahan hukum dan buku-buku atau kitab undang-undang yang berhubungan dengan obyek kajian. Hal ini dikarenakan penelitian ini merupakan penelitian literatur. Adapun bahan hukum yang digunakan terdiri dari bahan primer, bahan sekunder dan bahan tersier:

\footnotetext{
${ }^{4}$ Soerjono Soekanto dan Sri Mamudji, Penelitian Hukum Normatif Suatu Tinjauan Singkat, Cet. XI (Jakarta: PT. Raja Grafindo Persada, 2009), h. 13-14.

5 M. Nasution, Metode Penelitian Kualitatif, (Bandung: PT Remaja Rosydakarya, 2000), h. 2.

"Penulis menggunakan istilah "bahan hukum" sebagaimana yang dikemukakan Prof. Peter Mahmud Marzuki. Ia membedakan antara istilah "data" dan "bahan" karena dua alasan. Pertama, istilah "bahan" adalah terjemahan dari bahasa Inggris yang disebut material. Sementara "data" lebih bersifat informasi. Dalam penelitian normatif, sistem hukum dianggap telah mempunyai seluruh material/bahan, sehingga tidak perlu dicari ke "luar" dari sistem. Kedua, isitilah bahan digunakan untuk sesuatu yang normatif dan dokumentatif, bahan hukum dicari dengan cara penelitian kepustakaan, sementara data digunakan untuk sesuatu yang informatif empiris dalam penelitian yuridis empiris yang harus dicari melalui observasi ke dunia nyata. Lihat, Peter Mahmud Marzuki, Penelitian Hukum, (Jakarta: Kencana Prenada Media Group, 2006), h. 141-169.
} 
1. Sumber hukum primer: fatwa-fatwa yang dikeluarkan Dewan Syariah NasionalMajelis Ulama Indonesia. Undang-Undang Republik Indonesia khususnya UU No. 21 Tahun 2008 tentang Perbankan Syariah, dan Peraturan Bank Indonesia yang membahas persoalan Perbankan.

2. Sumber hukum sekunder: adalah doktrindoktrin yang ada di dalam buku, jurnal hukum, artikel majalah, koran, e-book dan data internet yang memuat pendapat para pakar dan praktisi dalam hal-hal yang memiliki relevansi dengan permasalahan yang menjadi fokus kajian penelitian.

3. Sumber bahan tersier: bahan tersier ini dapat berupa kamus, ensiklopedia, terjemahan Al-Qur'an dan bahan lainnya yang dianggap berhubungan dengan tema penelitian.

\section{d. Teknik Pendekatan}

Pendekatan dalam penelitian hukum dimana objeknya berupa norma yang sifatnya preskriptif, dapat dilakukan melalui:

\section{Pendekatan Undang-Undang (statute approach)}

2. Pendekatan Konseptual (conceptual approach)

3. Pendekatan Historis (bistorical approach) ${ }^{7}$

\section{e. Teknik Analisa Data}

1. Menggunakan logika berfikir deduktif, yakni menghimpun bahan penelitian yang bersifat umum menjadi bagian-bagian yang akan dibahas sesuai dengan tema penelitian dalam Bab dan Subbab yang telah ditentukan.

2. Setelah proses pengumpulan bahan penelitian selesai, dilakukan proses reduksi (seleksi bahan).

3. Penyajian bahan. Ini merupakan proses diskripsi atau penyusunan bahan-bahan menjadi teks naratif .

4. Penyimpulan data. ${ }^{9}$ Penarikan kesimpulan ini menggunakan metode deduktif dan komparatif.

\section{Ibid., h. 93.}

8 Muhammad Mufid, Nalar Ijtihad Fiqh Mubammad Sa'id Ramadhan al-Buthi (Banjarmasin: Antasari Press Banjarmasin, 2013), h. 22.

9 Sugiyono, Memahami Penelitian Kualitatif (Bandung: Alfabeta, tth), h. 99.

\section{SAJIAN DATA}

\section{Transformasi Fatwa Dewan Syariah Nasional ke Dalam Hukum Positif}

Para praktisi ekonomi syariah, masyarakat dan pemerintah (regulator) membutuhkan fatwafatwa syariah dari lembaga ulama (MUI) berkaitan dengan praktik dan produk di lembaga-lembaga keungan syariah tersebut. Perkembangan lembaga keuangan syariah yang demikian cepat harus diimbangi dengan fatwa-fatwa hukum syariah yang valid dan akurat, agar seluruh produknya memilik landasan yang kuat secara syariah. Untuk itulah Dewan Pengawas Syariah Nasional (DSN) dilahirkan pada tahun 1999 sebagai bagian dari Majelis Ulama Indonesia. ${ }^{10}$

Sejak berdirinya tahun 1999 hingga tahun 2016, Dewan Syariah Nasional, telah mengeluarkan sedikitnya 107 fatwa tentang ekonomi syariah, antara lain fatwa tentang giro, tabungan, murabahah, jual beli salam, istishna', mudharabah, musyarakah, jarah, wakalah, kafalah, hawalah, uang muka dalam murabahah, sistem distribusi hasil usaha dalam lembaga keuangan syariah, diskon dalam murabahah, sanksi atas nasabah mampu yang menunda-nunda pembayaran, pencadangan penghapusan aktiva produktif dalam LKS, al-qardh, investasi rekasadana syariah, pedoman umum asuransi syariah, jual beli istishna paralel, potongan pelunasan dalam murabahah, safe deposit box, rahn (gadai), rahn emas, ijarah muntabiya bit tamlik, jual beli mata uang, pembayaan pengurusan haji d LKS, pembiayaan rekening koran syariah, pengalihan utang, obligasi syariah, obligasi syariah mudharabah, Letter of Credit (LC) impor syariah, LC untuk ekspor, sertfikat Wadiah Bank Indonesia, Pasar Uang antar-Bank Syariah, sertifikat investasi mudharabah (IMA), asuransi haji, pedoman untuk penerapan prinsip syariah di pasar modal, obligasi syariah, kartu kredit, dan sebagainya. ${ }^{11}$

Struktur dan format fatwa sudah memadai dengan rumusan yang simpel. Jika dibandingkan dengan format fatwa mufti Mesir, misalnya fatwa DSN MU lebih komplit muatannya. Namun, format fatwa DSN MUI hanya terbatas memberikan

10 Lihat, Agustino, Penulis adalah Dosen Ekonomi dan Keuangan Syariah Pascasarjana PSTTI UI, Sekjen DPP IAEI dan Dosen Pascasarjana Ekonomi dan Keuangan Syariah di Universitas Indonesia Jakarta, di kutip dari internet, www.google.com, April 2013.

${ }^{11}$ DSN MUI, Fatwa, http://www.dsnmui.or.id/index. php?page $=$ fatwa, diakses pada Februari 2017 
penentuan status hukum masalah yang difatwakan, belum bersifat ifadah 'ilmiah yakni memberikan kegunaan pencerahan wawasan keilmuan, sehingga kurang memberikan bekal kepada kalangan di luar para ulama ekonomi syariah. Karena itu disarankan agar setiap fatwa disertai lampirannya, berupa uraian ilmiah singkat yang mengantarkan pada kesimpulan-kesimpulan isi fatwa. Fatwa dimaksud sudah disebarkan oleh MUI Pusat ke MUI Provinsi, Kabupaten/Kota dan juga sudah ada yang sampai kepada warga masyarakat, agar umat mengetahui hukum-hukum ekonomi syariah. ${ }^{12}$

Seperti yang dijelaskan sebelumnya bahwa fatwa tidak dapat dijadikan sebagai landasan hukum karena dalam sumber hukum positif dalam sistem hukum nasional dan dalam tata urutan peraturan perundang-undangan, sebagaimana telah disebutkan dalam Undang-Undang No 12 Tahun 2011 tentang Pembentukan Peraturan Perundangundangan, tidak menyebutkan fatwa sebagai bagian dari dasar hukum di negara ini. Namun agar fatwa dapat memiliki kekuatan hukum, maka fatwa harus dituangkan ke dalam Peraturan Bank Indonesia terutama fatwa yang dikeluarkan oleh Dewan Syariah Nasional. Hal ini sesuai dengan isi dari Undang-undang Perbankan Syariah No. 21 Tahun 2008.

UU No. 21 Tahun 2008 diperkirakan akan memiliki dampak positif, antara lain terhadap aspek kepatuhan syariah (shari'ah complience), iklim investasi dan kepastian usaha, serta perlindungan konsumen dan stabilitas sektor perbankan secara keseluruhan. Beberapa aspek penting lain dalam UU No. 21 Tahun 2008 tampak sudah berada pada arah yang tepat, antara lain:

1. Ketentuan bahwa bank konvensional dapat dikonversi menjadi bank syariah dan larangan bank syariah dan bank perkreditan syariah dikonversi menjadi bank konvensional dan bank perkreditan rakyat

2. Mengizinkan kepemilikan asing di sektor perbankan syariah domestik

3. Memfasilitasi spin-off unit usaha syariah menjadi bank umum syariah, tetapi tidak mewajibkannya

4. Dalam hal terjadi merger atau konsolidasi bank syariah dengan bank lain, bank hasil

12 Zainuddin Ali, Hukum Ekonomi Syariah (Jakarta: Sinar Grafika, 2008), h. 130-131. merger atau konsolidasi harus menjadi bank syariah

5. Dana zakat dan sosial yang dihimpun perbankan syariah harus disalurkan ke organisasi pengelola zakat

6. Penegasan dan landasan yang kuat tentang dewan pengawas syariah

7. Penegasan tentang kedudukan dewan syariah nasional

8. Kewajiban tata kelola yang baik dan penyampaian laporan keuangan berdasarkan prinsip akuntansi syariah. ${ }^{13}$

Di Indonesia, perkembangan fatwa DSNMUI sehingga diharuskan dituangkan menjadi sebuah Peraturan Bank Indonesia dapat diuraikan sebagai berikut:

1980 : Muncul ide dan gagasan konsep lembaga keuangan syariah, uji coba BMT Salman di Bandung dan Koperasi Ridho Gusti.

1990 : Lokakarya MUI dimana para peserta sepakat mendirikan bank syariah di Indonesia.

1992 : Pada tanggal 1 Mei 1992 bank syariah pertama bernama Muamalah Indonesia mulai beroperasi.

1992 : Kemunculan BMI ini kemudian diikuti dengan lahirnya UU No. 7 Tahun 1992 tentang Perbankan yang mengakomodasi perbankan dengan prinsip bagi hasil baik bank umum maupun BPRS.

1998 : Keluar UU No. 10 Tahun 1998 tentang perubahan UU No. 7 tahun 1992 yang mengakui keberadaan bank syariah dan bank konvensional serta memperkenankan bank konvensional membuka kantor cabang syariah.

1999 : Keluar UU No. 23 Tahun 1999 tentang Bank Indonesia yang mengakomodasi kabijakan moneter berdasarkan prinsip syariah dimana BI bertanggung jawab terhadap pengaturan dan pengawasan bank komersial termasuk bank syariah. BI dapat menetapkan kebijakan moneter dengan menggunakan prinsip syariah. Pada tahun ini dibuka kantor cabang bank syariah untuk pertama kali.

2000 : BI mengeluarkan regulasi operasional dan kelembagaan bank syariah dimana BI menetapkan peraturan kelembagaan perbankan

13 Ika Novianti, Perbankan Syariah di Indonesia, http:// wordpress.com., di tulis pada Februari 2013, diakses pada September 2013. 
syariah. Pengembangan Pasar Uang Antarbank Syariah (PUAS) dan Sertifikat Wadiah Bank Indonesia (SWBI) sebagai instrument Pasar Uang Syariah.

2001 : Pendirian unit kerja Biro Perbankan Syariah di Bank Indonesia untuk menangani perbankan syariah.

2002 : Peraturan BI No. 4/ 1/ 2002 mengenai pengenalan pembuktian bersih cabang syariah yang merupakan penyempurnaan jaringan kantor cabang syariah.

2004 : Keluar UU No. 3 Tahun 2004 tentang perubahan UU No. 23 Tahun 1999 tentang Bank Indonesia yang makin mempertegas penetapan kebijakan moneter dengan yang dilakukan oleh BI dapat dilakukan dengan prinsip syariah. Belakangan UU N0. 23 tahun 1999 diubah dengan Peraturan Pemerintah Pengganti Undang-Undang Nomor 2 Tahun 2008. Di samping itu, BI juga menyiapkan peraturan standarisasi akad, tingkat kesehatan, dan Lembaga Penjamin Simpanan. Di tahun ini juga terjadi perubahan Biro Perbankan Syariah menjadi Direktorat Perbankan Syariah di Bank Indonesia.

2005 : Di era UU No. 10/ 1998 secara teknis mengenai produk mengacu pada PBI No. 7/46/ PBI/2005, tentang Akad Penghimpunan dan Penyaluran Dana bagi bank yang Melaksanakan Kegiatan Usaha Berdasarkan Prinsip Syariah, yang kemudian sudah diganti dengan PBI N0.9/19/PBI/2007 tentang Pelaksanaan Prinsip Syariah dalam Kegiatan Penghimpunan Dana dan Penyalur Dana Serta Pelayanan Jasa Bank Syariah.

2006 : Pemberian layanan syariah juga semakin dipermudah dengan diperkenalkannya konsep office channeling, yakni semacam counter layanan syariah yang terdapat di kantor cabang/kantor cabang pembantu bank konvensional yang sudah memiliki UUS. Hal demikian ditemukan dalam PBI No. 8/3/PBI/2006 tentang Perubahan Kegiatan Usaha Bank Umum Konvensional Menjadi Bank Umum yang Melaksanakan Kegiatan Usaha Berdasarkan Prinsip Syariah dan Pembukaan Kantor Bank yang Melaksanakan Kegiatan Usaha Berdasarkan Prinsip Syariah oleh Bank Umum Konvensional. Produk bank syariah terdiri dari produk penghimpunan dana (funding), produk penyaluran dana (lending), jasa (services), dan produk di bidang sosial.

2008 : Pada tanggal 16 Juli 2008 UU No. 21 Tahun 2008 tentang Perbankan Syariah disahkan yang memberikan landasan hukum industri perbankan syariah nasional dan diharapkan mendorong perkembangan bank syariah yang selama lima tahun terakhir asetnya tumbuh dari $65 \%$ per tahun namun pasarnya (market share) secara nasional masih di bawah 5\%. Undang-undang ini mengatur secara khusus mengenai perbankan syariah, baik secara kelembagaan maupun kegiatan usaha. Beberapa lembaga hukum baru diperkenalkan dalam UU No. 21/2008, antara lain yakni menyangkut pemisahan (spin-off) UUS baik secara sukarela maupun wajib dan Komite Perbankan Syariah. Terdapat beberapa PBI yang diamanahkan oleh UU No. $21 / 2008 .^{14}$

Proses penerbitan sebuah fatwa dapat dilihat pada skema di bawah ini:

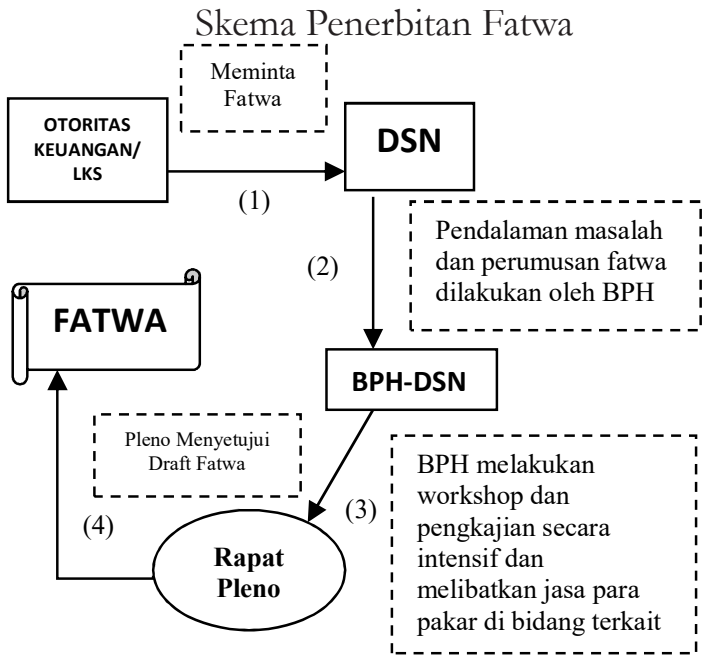

Penjelasan dari skema di atas adalah sebagai berikut:

DSN mengeluarkan fatwa mengenai suatu produk, jasa dan ketentuan setelah mendapatkan suatu permohonan fatwa dari otoritas moneter atau LKS

1. BPH-DSN melakukan pengkajian secara mendalam mengenai persoalan yang diminta fatwanya dengan melakukan rapat intensif dan workshop

2. BPH-DSN merumuskan draft fatwa untuk kemudian dibahas lebih lanjut dalam rapat pleno DSN

\footnotetext{
14 Andri Soemitra, Bank dan Lembaga Kenangan Syariah (Jakarta: Kencana, 2009), h. 63-65.
} 
3. Jika dalam rapat pleno DSN telah menyetujui draft fatwa, maka draft fatwa tersebut telah sah menjadi fatwa.

Selain itu hubungan antara DSN dan Otoritas Keuangan seperti halnya BI dapat dilihat pada skema berikut:

Skema Hubungan Antara DSN Dengan Otoritas Keuangan

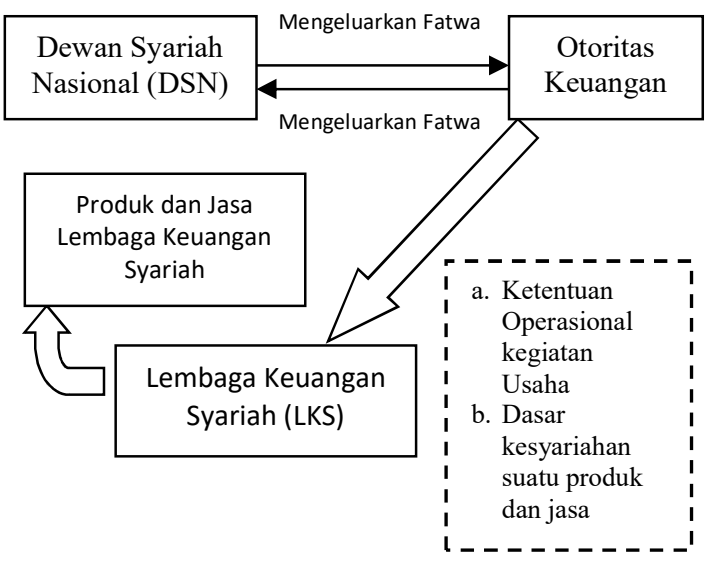

\section{ANALISIS DATA}

Dari penjelasan di atas dapat dilihat proses transformasi fatwa Dewan Syariah Nasional hingga menjadi hukum positif. Adapun transformasi fatwa tersebut merupakan suatu perubahan bentuk, dari produk penalaran fuqaha yang "beragam" (mukbtalaf fib) menjadi produk badan penyelenggara negara yang bersifat "seragam" (muttafaq 'alayh), yakni peraturan perundang-undangan (al-qänun)..$^{15}$ Perubahan bentuk tersebut, dalam berbagai hal diikuti oleh perubahan substansi, sehingga dapat dikatakan sebagai perubahan struktural dalam konteks struktur dan kultur masyarakat bangsa karena adanya faktor determinan yang bersifat

\footnotetext{
15 Di Indonesia, berdasarkan Ketetapan MPR-RI Nomor III Tahun 2000 tata urut peraturan perundang-undangan adalah sebagai berikit: (1) Undang-Undang Dasar 1945; (2) Ketetapan MPR-RI; (3) Undang-Undang; (4) Peraturan Pemerintah Pengganti Undang-Undang; (5) Peraturan Pemerintah; (6) Keputusan Presiden; dan (7) Peraturan Daerah (Provinsi dan Kabupaten/ Kota). Sementara itu, menurut ketentuan Pasal 7 ayat (1) Undang-Undang Nomor 12 Tahun 2011 tentang Pembentukan Peraturan Perundang-undangan, hirarki Peraturan Perundang-undangan adalah sebagai berikut: (1). Undang-Undang Dasar Negara Republik Indonesia Tahun 1945; (2) Ketetapan Majelis Permusyarakatan Rakyat; (3) Undang-Undang/Peraturan Pemerintah Pengganti Undang-Undang (Perpu); (4) Peraturan Pemerintah; (5) Peraturan Presiden; (6) Peraturan Daerah Provinsi (7) Peraturan Daerah Kabupaten/Kota.
}

konstan bagi perubahan kehidupan manusia secara semesta. Transformasi itu bermakna suatu proses kontekstualisasi norma figh (sebagai majmū'at alablkäm) ke dalam struktur masyarakat bangsa. Dalam proses itu terjadi reduksi, adaptasi, dan modifikasi norma fiqh yang "anti struktur" menjadi hukum positif yang "terstruktur", yang memiliki daya ikat serta daya atur. Bahkan, dalam hal tertentu, hukum positif memiliki daya paksa. Dengan demikian, ketika fatwa ditransformasi ke dalam hukum positif ia telah mengalami perubahan wujud dan fungsi dalam konteks sistem hukum nasional. ${ }^{16}$ Fatwa telah terintegrasi dengan norma lain, yang telah berubah bentuk menjadi hukum positif. Bahkan dalam hal tertentu mengalami perubahan makna, baik dalam arti perluasan makna maupun penyempitan makna.

Atas perihal tersebut, dalam bidang tertentu di Indonesia, misalnya, makna subyek hukum mengalami perluasan, dari orang (naturlijk persoon) menjadi orang dan atau badan hukum (rechtspersoon) sebagaimana tampak dalam hukum perwakafan (wakif dan nadzir) dan hukum pengelolaan zakat (muzakki dan mustahiq). Hal itu tampak dalam ketentuan Pasal 7 Undang-Undang Nomor 41 Tahun 2004, wakif terdiri atas perseorangan, organisasi, dan badan hukum yang mewakafkan benda miliknya. Sedangkan nadzir adalah kelompok orang atau badan hukum yang diserahi tugas pemeliharaan dan penguasaan benda wakaf. Sementara itu, menurut ketentuan Pasal 1 Undang-Undang Nomor 38 Tahun 1999 tentang Pengelolaan Zakat, muzakki adalah orang atau badan hukum yang dimiliki oleh Muslim yang berkewajiban menunaikan zakat. Sedangkan mustabiq adalah orang atau badan hukum yang berhak menerima zakat.

Usaha-usaha yang demikian, menjadikan fatwa sebagai salah satu bahan baku dalam penyusunan hukum positif. Atau, sebagaimana dikemukakan oleh Abdurrahman Wahid, "Apa yang dituju adalah bagaimana menjadikan hukum Islam lebih banyak lagi menggunakan pertimbangan-pertimbangan manusiawi, termasuk pertimbangan ilmiah praktis, dalam proses pengambilan keputusan hukumnya". Dengan perkataan lain, usaha seperti itu menjadikan (sebagian) fatwa terintegrasi ke dalam hukum positif. Ia menjadi hukum yang mengikat, mengatur,

\footnotetext{
16 Yang dimaksud dengan hukum positif dalam tulisan ini, khusunya di Indonesia, ialah peraturan perundangundangan sebagaimana yang dimaksud dalam UndangUndang Nomor 12 Tahun 2011 tentang Pembentukan Peraturan Perundang-undangan.
} 
dan dapat dilaksanakan bagi penataan kehidupan manusia.

Pada tahapan ini terjadi proses pengalihan substansi fatwa ke dalam hukum positif ketika terdapat titik persamaan antara substansi fatwa dengan "bahan baku" lain dalam perumusan hukum positif lebih besar ketimbang perbedaannya. Hal itu terjadi ketika interaksi antara elite Islam dengan elite lain dilakukan dengan frekuensi dan intensitas yang sangat tinggi

Apa yang dikemukakan di atas menunjukkan bahwa fatwa memiliki potensi dan posisi dalam sistem hukum nasional yang bersumber pada hukum positif. Kini, di samping civil law system, dan common law system, juga berkembang Islamic law system yang intinya adalah fatwa.

Perjalanan bank syariah masih panjang dan berliku. Keberadaan UU tidak cukup membuat fundamental bank syariah kuat dan berkembang. Kekuatan SDM adalah kunci dari arah dan masa depan bank syariah. Saat ini, bank syariah memerlukan SDM-SDM yang holistik-integratif: memiliki kemampuan yang memukau di bidang keuangan tetapi juga tidak "rikuh" dengan teksteks fiqh klasik. Dengan SDM yang tangguh, masalah inovasi produk, shariah compliant, edukasi dan sosialisasi akan teratasi. Bahkan dengan SDM yang qualified, keterbatasan permodalan dan jaringan pun akan mudah dicarikan jalan keluarnya. Hal ini berlaku pula ketika hukum Islam ingin dikodifikasikan menjadi hukum positif. Dengan SDM yang berkualitas dan mempuni tentu hal tersebut akan mudah dilakukan.

Ada tiga hal yang perlu diperhatikan dalam hal transformasi fatwa Dewan Syariah Nasional (DSN) ke dalam hukum positif. Tiga hal tesebut yakni fatwa, transformasi fatwa dan hukum positif. Hal pertama ialah fatwa yang merupakan harapan umat Islam agar hukum Islam dapat menjadi hukum positif di Indonesia. Fatwa di sini yakni fatwa yang dikeluarkan oleh DSN-MUI yang telah diakui oleh negara dalam UU No. 21 tahun 2008 tentang Perbankan Syariah sehingga membuka jalan bagi hukum-hukum Islam dapat dikodifikasikan terutama dalam Perbankan Syariah.

Hal kedua ialah transformasi fatwa ke dalam hukum positif dalam sistem hukum nasional. Ia merupakan pengalihan substansi fatwa ke dalam substansi hukum positif, yang meliputi empat tataran hukum, yakni (1) tataran asas atau prinsip hukum;
(2) tataran hukum material (hukum substantif) ${ }^{17}$; (3) tataran hukum formal (hukum acara) ${ }^{18}$; dan (4) tataran pelaksanaan hukum atau penegakan hukum. Transformasi itu dilaksanakan berdasarkan politik hukum dari badan penyelenggara negara yang ditindaklanjuti oleh program legislasi.

Hal ketiga ialah hukum positif. Seperti yang telah dijelaskan sebelumnya, ketika fatwa ditransformasi ke dalam hukum positif ia telah mengalami perubahan wujud dan fungsi dalam konteks sistem hukum nasional. ${ }^{19}$ Oleh sebab itu ketika membahas hukum positif, maka konteks sistem hukum nasional yang akan menjadi pembahasan. Sistem hukum nasional merupakan bagian dari sistem masyarakat dalam ikatan negara kebangsaan. Dalam sistem hukum itu mencakup beberapa hal. Pertama, nilai-nilai fundamental yang telah disepakati sebagai rujukan utama sebagaimana tersurat dalam konstitusi. Kedua, bahan baku dalam pembentukan dan pengembangan hukum. Ketiga, arah pengembangan hukum yang hendak dicapai. Keempat, berbagai bidang kehidupan yang memerlukan pengaturan. Kelima, proses politik melalui suprastruktur dan infrastruktur politik. Keenam, perangkat hukum dalam jenjang hukum tertulis yang ditetapkan oleh badan penyelenggara negara. Ketujuh, penegakan hukum melalui badan dan aparat penegakan hukum. Kedelapan, pluralitas dan perkembangan masyarakat bangsa secara internal. Kesembilan, perkembangan masyarakat dunia yang ditunjang oleh produk teknologi (eksternal). Berbagai hal itu merupakan unsur (subsistem) dalam sistem hukum nasional sebagai suatu kesatuan terintegrasi yang saling berhubungan, saling menunjang, dan saling tergantung.

Proses transformasi merupakan tahapan pengalihan substansi fatwa ke dalam hukum positif.

\footnotetext{
17 Sumber hukum material/materiil, yaitu sumber hukum perasaan hukum (keyakinan hukum) individu dan pendapat umum (public opinion) yang menjadi determinan materiil membentuk hukum, menentukan isi hukum. Lihat Zafrullah Salim, "Kedudukan Fatwa dalam Negara Hukum Republik Indonesia," dalam Tim, Fatwa Majelis Ulama Indonesia (MUI) dalam Perspektif Hukum dan Perundang-undangan (Jakarta: Puslitbang Kehidupan Keagamaan Badan Litbang dan Diklat Kementerian Agama RI, 2012), h. 27.

18 Sumber hukum formil, yaitu yang menjadi diterminan formil membentuk hukum (formale determinanten van de rechtsvorming) menentukan berlakunya hukum. Lihat Zafrullah Salim, "Kedudukan Fatwa ...," dalam Ibid. 19 Lihat pada BAB III Paparan Data.
} 
Tahapan tersebut dilakukan melalui suatu prosedur yang berlaku pada negara yang bersangkutan. Prosedur itu juga berhubungan dengan sistem pemerintahan yang dianut: presidensial atau parlementer. Tahapan itu secara teknis meliputi: tahap perencanaan, penyusunan, pembahasan, pengesahan atau penetapan, dan pengundangan. ${ }^{20}$ Tahap perencanaan penyusun undang-undang dilakukan dalam suatu Program Legislasi Nasional (Prolegnas). Bertujuan agar dalam pembentukan peraturan perundang-undangan dapat dilaksanakan secara berencana. Memuat skala prioritas program legislasi tingkat nasional sesuai jangka menengah atau tahunan yang disusun oleh DPR dengan perkembangan kebutuhan dalam mewujudkan sistem hukum nasional. Tahap selanjutnya yakni tahap penyusunan. Tahap penyusunan undang-undang pada dasarnya dibedakan menjadi 3 proses yaitu, RUU dari DPR dan presiden, RUU dari presiden, dan RUU dari DPD. Semua tersebut harus disertai Naskah Akademik, ${ }^{21}$ disusun berdasarkan Polegnas. Tahap pembahasan RUU dilakukan oleh DPR dan Presiden atau menteri yang di tugasi. RUU yang berkaitan dengan otonomi daerah mengikutsertakan DPD. Keikutsertaan DPD hanya sampai tingkat I. DPD meberikan pertimbangan kepada DPR atas Anggaran Pendapatan dan Belanjaan Negara. Pembicaraan melalui dua tingkat sebagai berikut. Pertama, pembicaraan tingkat I dalam rapat komisi, rapat gabungan, rapat badan legislasi, rapat badan anggaran, atau rapat panitia khusus. Dilakukan dengan kegiatan mini. Kedua, pembicaraan tingkat II dalam rapat paripurna. ${ }^{22}$ Pada tahap pengesahan

20 Lihat UU No. 12 Tahun 2011 tentang Pembentukan Peraturan Perundang-undangan, Pasal 1, Ayat 1.

21 Naskah akademik adalah naskah hasil penelitian atau pengkajian hukum dan hasil penelitian lainnya terhadap suatu masalah tertentu yang dapat dipertanggungjawabkan secara ilmiah mengenai pengaturan masalah tersebut dalam suatu Rancangan Undang undang, Rancangan Peraturan Daerah Provinsi atau Rancangan Peraturan Daerah Kabupaten/Kota sebagai solusi terhadap permasalahan dan kebutuhan hukum masyarakat. Lihat UU No. 12 Tahun 2011 tentang Pembentukan Peraturan Perundang-undangan. Keberadaan Naskah Akademik awalnya belum menjadi suatu keharusan dalam penyusunan Rancangan Peraturan Perundang undangan. Menjadi harus sejak tahun 2011, sesuai ketentuan Pasal 43 ayat (3) UU No. 12 Tahun 2011 tentang Pembentukan Peraturan Perundang-undangan.

22 Rizqiyliapratiwi, Tahap Pembentukan Peraturan Perundangundangan di bawah UUD 1945, http://rizqyliapratiwi.
RUU yang telah disetujui oleh DPR dan presiden disampaikan oleh pemimpin DPR kepada presiden untuk disahkan menjadi undang-undang. Disahkan setelah 7 hari keputusan bersama membubuhkan tanda tangan paling lama 30 hari sejak keputusan bersama Penetapan peraturan daerah dilakukan oleh kepala daerah setelah mendapat persetujuan DPRD. Paling lambat 7 hari disampaikan kepada kepala daerah setelah keputusan dalam jangka waktu paling lambat 30 hari mendapatkan tanda tangan kepala daerah. Tahap terakhir yakni pengundangan. Peraturan perundang-undangan dalam berita NKRI. Tambahan Lembaran Negara Republik Indonesia memuat penjelasan peraturan perundangundangan yang di muat dalam Berita Indonesia. Pengundangan peraturan perundang-undangan dilaksanakan oleh menteri yang menyelenggarakan urusan di bidang hukum.

Rujukan konstitusi merupakan rujukan yuridis dalam proses penyusunan hukum positif, sesuai dengan hierarki hukum positif yang berlaku dalam negara yang bersangkutan. Dalam konteks negara bangsa Indonesia, rujukan konstitusi tersebut adalah ketentuan dalam Undang-Undang Dasar 1945. Sementara itu, rujukan hukum positif di bawah undang-undang adalah undang-undang itu sendiri; dan seterusnya.

Selain itu perubahan sosial merupakan aspek sosiologis bagi transformasi fatwa. Ia merupakan aspek eksternal dalam proses transformasi fatwa melalui interaksi antara elite Islam dengan elite lainnya, termasuk elite penguasa. Manakala elite Islam mempunyai daya tawar yang tinggi, maka peluang transformasi fatwa lebih terbuka. Demikian pula sebaliknya. Boleh jadi interaksi itu tidak hanya terbatas dalam suatu negara, tetapi juga interaksi antar elite antar bangsa. Transformasi fatwa DSNMUI, khususnya bidang ekonomi syariah dan perbankan, misalnya, menunjukkan gejala yang mendunia.

Jika akan melihat kedudukan fatwa DSN dalam kerangka hukum nasional, maka kita perlu melihat posisi MUI dalam kerangka kelembagaan di pemerintah. Hal ini dikarenakan, kekuatan mengikat produk hukum yang dikeluarkan oleh satu lembaga akan dipengaruhi oleh posisi lembaga tersebut dalam tata pemerintahan. MUI dalam ketatanegaraan Indonesia sebenarnya berada dalam elemen infra struktur ketatanegaraan (lebih

wordpress.com/, ditulis pada Nopember 2012, diakses pada Januari 2014. 
berada di ruang-ruang pemberdayaan masyarakat), sebab MUI adalah organisasi 'alim ulama umat Islam yang mempunyai tugas dan fungsi untuk memberdayakan masyarakat/umat Islam, artinya MUI adalah organisasi yang ada dalam masyarakat, dan bukan merupakan institusi milik negara atau merepresentasikan negara.

Fatwa MUI jika dilhat dalam kerangka hukum nasional maka fatwa tersebut tidak mempunyai kekuatan hukum mengikat. Akan tetapi fatwa memiliki kekuatan hukum yang mengikat apabila fatwa tersebut diperkuat dengan instrumentinstrumen negara yang mempunyai alat legitimasi, seperti Undang-undang, PP, PBI, atau sejenisnya. ${ }^{23}$ Di sinilah letak kedudukan strategis dari negara dalam pandangan Islam. Dalam sebuah negara Islam, fatwa merupakan produk hukum yang mengikat apabila diadopsi oleh pemerintah. Jadi mengikat atau tidaknya sebuah fatwa jika dilihat dari kerangka hukum nasional sangat tergantung apakah fatwa tersebut termasuk produk hukum yang diadopsi negara atau tidak. Hal ini yang menjadi masalah di Indonesia karena fatwa atau pendapat MUI itu hanya dijadikan sebagai masukan oleh pemerintah bukan sebagai hukum yang mengikat.

BI telah menjadikan fatwa sebagai bahan pertimbangan hukum pada masa sebelum UU No. 21 Tahun 2008 tentang Perbankan Syariah disahkan. Hal ini terlihat pada Kodifikasi Produk Perbankan Syariah yang memuat secara tertulis bahwa fatwa DSN tertentu menjadi rujukan pembuatan peraturan.

Fatwa yang telah dikeluarkan oleh DSN dari tahun 2008 hingga tahun 2013 adalah berjumlah 11 fatwa DSN dan PBI yang telah dikeluarkan oleh Bank Indonesia berkenaan dengan fatwa DSN tersebut sesuai dengan amanat UU No. 21 Tahun 2008 tentang Perbankan Syariah hingga tahun 2013 adalah berjumlah 21 buah PBI. ${ }^{24}$ Jika dilihat dari 21 jumlah PBI tersebut tidak ditemukan kesesuaian antara materi pembahasan fatwa DSN dengan PBI. Hal ini menimbulkan pertanyaan apakah benar fatwa tersebut dijadikan acuan dalam pembentukan PBI oleh Bank Indonesia melalui KPS. Selain itu, dari 21 PBI yang dikeluarkan, hanya 15 buah PBI yang dibuat setelah dibentuknya KPS oleh Bank Indonesia.

\footnotetext{
${ }^{23}$ M. Fauzan, Pokok-pokok Hukum Acara Perdata Peradilan Agama dan Mabkamah Syar'iyah di Indonesia (Jakarta: Kencana, 2005), h. 158.

${ }^{24}$ Fatwa DSN dan PBI dapat dilihat pada BAB III Paparan Data.
}

Adapun PBI tersebut antara lain:

1. PBI No. $11 / 3 / \mathrm{PBI} / 2009$ tentang Bank Umum Syariah. ${ }^{25}$

2. PBI No. $11 / 15 / \mathrm{PBI} / 2009$ tentang Perubahan Kegiatan Usaha Bank Konvensional Menjadi Bank Syariah.

3. PBI No. 11/24/PBI/2009 tentang Fasilitas Pendanaan Jangka Pendek Syariah Bagi Bank Umum Syariah

4. PBI No. 11/29/PBI/2009 tentang Fasilitas Pendanaa Jangka Pendek Syariah bagi Bank Pembiayaan Rakyat Syariah

5. PBI. No. 11/31/PBI/2009 tentang Uji Kemampuan Dan Kepatutan (Fit And Proper Test) Bank Syariah Dan Unit Usaha Syariah

6. PBI No. 11/33/PBI/2009 tentang Pelaksanaan Good Corporate Governance Bagi Bank Umum Syariah dan Unit Usaha Syariah.

7. PBI No. 13/5/PBI/2011 tentang Batas Maksimum Penyaluran Dana Bank Pembiayaan Rakyat Syariah.

8. PBI No. 13/6/PBI/2011 tentang Tindak Lanjut Penanganan Terhadap Bank Pembiayaan Rakyat Syariah dalam Status Penangan Khusus.

9. PBI No. 13/9/PBI/2011 tentang Perubahan atas Peraturan Bank Indonesia Nomor 10/18/PBI/2008 Tentang Restrukturisasi Pembiayaan Bagi Bank Syariah Dan Unit Usaha Syariah.

10.PBI No. 13/13/PBI/2011 tentang Penilaian Kualitas Aktiva Bagi Bank Umum Syariah Dan Unit Usaha Syariah.

11.PBI No. 13/14/PBI/2011 tentang Penilaian Kualitas Aktiva Bagi Bank Pembiayaan Rakyat Syariah.

12.PBI No. 13/23/PBI/2011 tentang Penerapan Manajemen Risiko Bagi Bank Umum Syariah dan Unit Usaha Syariah.

13.PBI No. 14/6/2012 tentang Uji Kemampuan Dan Kepatutan (Fit And Proper Test) Bank Syariah dan Unit Usaha Syariah.

14.PBI No. 14/17/2012 tentang Kegiatan Usaha Bank Berupa Penitipan Dengan Pengelolaan (Trust)

\footnotetext{
25 Andri Soemitra, Bank dan Lembaga Keuangan Syariab (Jakarta: Kencana, 2009), h. 66.
} 
15.PBI No. 14/20/PBI/2012 tentang Perubahan Atas Peraturan Bank Indonesia No. 11/24/ PBI/2009 tentang Fasilitas Pendanaan Jangka Pendek Syariah Bagi Bank Umum Syariah. ${ }^{26}$

Dari 15 PBI tersebut dapat dinilai apakah ada penyerapan fatwa DSN sebagai bahan pertimbangan dalam pembuatan PBI oleh KPS. Karena telah diketahui bahwa salah satu amanat bagi Bank Indonesia adalah pembentukan Komite Perbankan Syariah (KPS) dalam rangka mengimplementasikan fatwa Majelis Ulama Indonesia (MUI) yang akan dituangkan dalam Peraturan Bank Indonesia. Fatwa MUI yang memuat Prinsip Syariah merupakan salah satu aspek mendasar atas keberadaan, kelangsungan dan pengembangan industri perbankan syariah di Indonesia. Dalam rangka implementasi dan harmonisasi fatwa agar dapat dituangkan dengan baik ke dalam Peraturan Bank Indonesia, maka tahapan penafsiran dan pemaknaan fatwa merupakan satu tahapan yang penting dalam proses penyusunan ketentuan berupa Peraturan Bank Indonesia.

Jika pada masa sebelum UU No. 21 Tahun 2008 tentang Perbankan Syariah disahkan fatwa secara jelas dimuat sebagai bahan pertimbangan hukum oleh BI, maka setelah lahirnya UU tersebut, khususnya setelah KPS terbentuk, BI tidak memuat secara eksplisit tentang fatwa yang menjadi rujukan pembuatan PBI dalam redaksi kalimat PBI sehingga menimbulkan kebingungan ketika seseorang ingin mengetahui fatwa apa yang telah diserap dalam PBI tersebut. Namun jika diteliti lebih mendalam, maka ada beberapa dari PBI tersebut yang memuat unsur Fatwa dari DSN walaupun tidak disebutkan di dalamnya. Hal ini dapat dilihat pada tabel di bawah ini:

\section{Penyerapan Fatwa DSN oleh PBI Paska dibentuknya KPS}

\begin{tabular}{|c|l|l|l|l|}
\hline No. & \multicolumn{1}{|c|}{ PBI } & $\begin{array}{c}\text { Bagian } \\
\text { PBI }\end{array}$ & \multicolumn{1}{|c|}{$\begin{array}{c}\text { Fatwa } \\
\text { DSN }\end{array}$} & $\begin{array}{c}\text { Perihal } \\
\text { Fatwa }\end{array}$ \\
\hline 1. & PBI No. & - & - & - \\
& $11 / 3 /$ & & & \\
& PBI/2009 & & & \\
& tentang & & & \\
& Bank & & & \\
& Umum & & & \\
& Syariah. & & & \\
\hline
\end{tabular}

\begin{tabular}{|c|c|c|c|c|}
\hline 2. & $\begin{array}{l}\text { PBINo. } \\
11 / 15 / \\
\text { PBI/2009 } \\
\text { tentang } \\
\text { Perubahan } \\
\text { Kegiatan } \\
\text { Usaha Bank } \\
\text { Konven- } \\
\text { sional Men- } \\
\text { jadi Bank } \\
\text { Syariah }\end{array}$ & - & - & - \\
\hline 3. & $\begin{array}{l}\text { PBINo. } \\
11 / 24 / \\
\text { PBI/2009 } \\
\text { tentang } \\
\text { Fasilitas } \\
\text { Pendanaan } \\
\text { Jangka } \\
\text { Pendek } \\
\text { Syariah } \\
\text { Bagi Bank } \\
\text { Umum } \\
\text { Syariah }\end{array}$ & $\begin{array}{l}\text { Pasal 3, } \\
\text { yang ber- } \\
\text { bunyi: FP- } \\
\text { JPS yang } \\
\text { diterima } \\
\text { oleh Bank } \\
\text { sebagaima- } \\
\text { na dimak- } \\
\text { sud dalam } \\
\text { Pasal } 2 \\
\text { ayat (1) } \\
\text { berdasar- } \\
\text { kan akad } \\
\text { Mudhara- } \\
\text { bah. }\end{array}$ & $\begin{array}{l}\text { Fatwa } \\
\text { DSN No. } \\
\text { 7/DSN- } \\
\text { MUI/ } \\
\text { IV/2000 }\end{array}$ & $\begin{array}{l}\text { tentang } \\
\text { Pem- } \\
\text { biayaan } \\
\text { Mud- } \\
\text { harabah } \\
\text { (Qiradh) }\end{array}$ \\
\hline 4. & $\begin{array}{l}\text { PBINo. } \\
11 / 29 / \\
\text { PBI/2009 } \\
\text { tentang } \\
\text { Fasilitas } \\
\text { Pendanaa } \\
\text { Jangka } \\
\text { Pendek } \\
\text { Syariah } \\
\text { bagi Bank } \\
\text { Pembiayaan } \\
\text { Rakyat } \\
\text { Syariah }\end{array}$ & $\begin{array}{l}\text { Pasal 3, } \\
\text { yang ber- } \\
\text { bunyi: FP- } \\
\text { JPS yang } \\
\text { diterima } \\
\text { oleh BPRS } \\
\text { menggu- } \\
\text { nakan akad } \\
\text { Mudhara- } \\
\text { bah. }\end{array}$ & $\begin{array}{l}\text { Fatwa } \\
\text { DSN No. } \\
\text { 7/DSN- } \\
\text { MUI/ } \\
\text { IV/2000 }\end{array}$ & $\begin{array}{l}\text { tentang } \\
\text { Pem- } \\
\text { biayaan } \\
\text { Mud- } \\
\text { harabah } \\
\text { (Qiradh) }\end{array}$ \\
\hline 5. & $\begin{array}{l}\text { PBI. No. } \\
11 / 31 / \\
\text { PBI/2009 } \\
\text { tentang Uji } \\
\text { Kemam- } \\
\text { puan Dan } \\
\text { Kepatutan } \\
\text { (Fit And } \\
\text { Proper } \\
\text { Test) Bank } \\
\text { Syariah Dan } \\
\text { Unit Usaha } \\
\text { Syariah }\end{array}$ & - & - & - \\
\hline
\end{tabular}

${ }^{26}$ Diambil dari website resmi Bank Indonesia. 


\begin{tabular}{|c|c|c|c|c|}
\hline 6. & $\begin{array}{l}\text { PBI No. } \\
11 / 33 / \\
\text { PBI/2009 } \\
\text { tentang } \\
\text { Pelaksa- } \\
\text { naan Good } \\
\text { Corporate } \\
\text { Governance } \\
\text { Bagi Bank } \\
\text { Umum } \\
\text { Syariah dan } \\
\text { Unit Usaha } \\
\text { Syariah. }\end{array}$ & - & - & - \\
\hline 7. & $\begin{array}{l}\text { PBINo. } \\
13 / 5 / \\
\text { PBI/2011 } \\
\text { tentang } \\
\text { Batas } \\
\text { Maksimum } \\
\text { Penyaluran } \\
\text { Dana Bank } \\
\text { Pembiayaan } \\
\text { Rakyat } \\
\text { Syariah. }\end{array}$ & - & - & 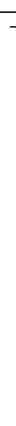 \\
\hline 8. & $\begin{array}{l}\text { PBINo. } \\
\text { 13/6/ } \\
\text { PBI/2011 } \\
\text { tentang } \\
\text { Tindak } \\
\text { Lanjut } \\
\text { Penanganan } \\
\text { Terhadap } \\
\text { Bank } \\
\text { Pembiayaan } \\
\text { Rakyat } \\
\text { Syariah da- } \\
\text { lam Status } \\
\text { Penangan } \\
\text { Khusus. }\end{array}$ & - & - & 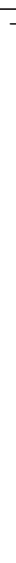 \\
\hline
\end{tabular}

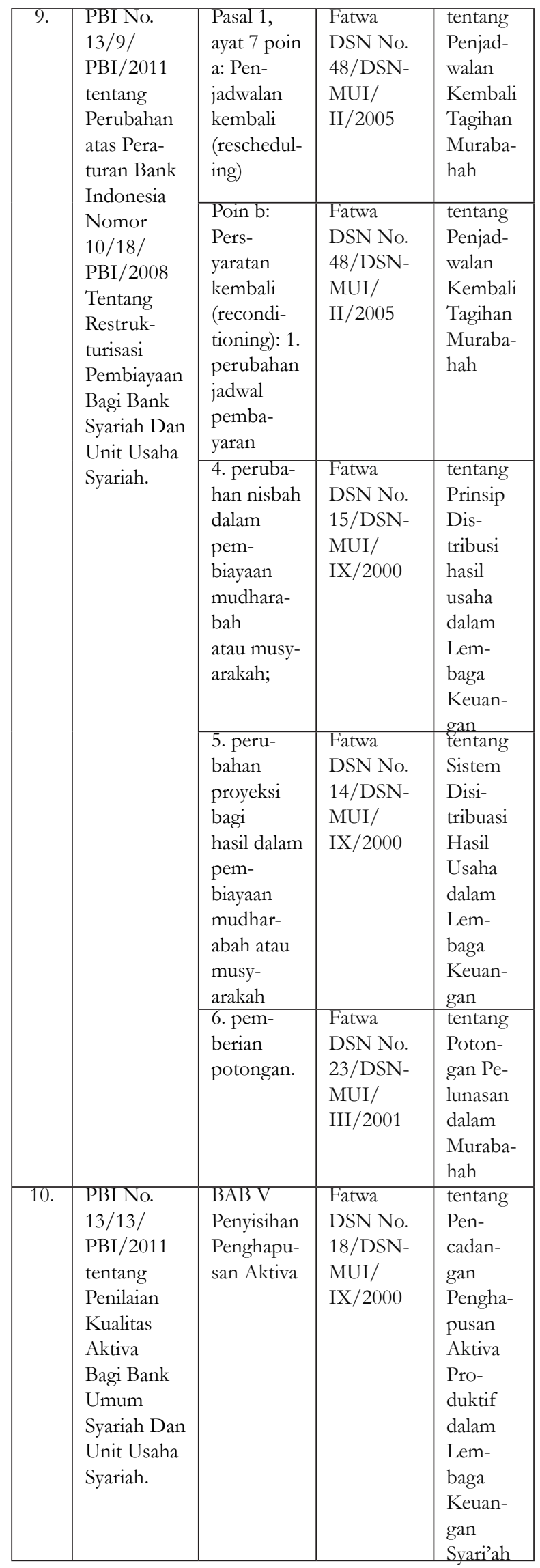




\begin{tabular}{|c|c|c|c|c|}
\hline 11. & $\begin{array}{l}\text { PBINo. } \\
\text { 13/14/ } \\
\text { PBI/2011 } \\
\text { tentang } \\
\text { Penilaian } \\
\text { Kualitas } \\
\text { Aktiva } \\
\text { Bagi Bank } \\
\text { Pembiayaan } \\
\text { Rakyat } \\
\text { Syariah. }\end{array}$ & $\begin{array}{l}\text { BAB VI } \\
\text { Penyisihan } \\
\text { Penghapu- } \\
\text { san Aktiva }\end{array}$ & $\begin{array}{l}\text { Fatwa } \\
\text { DSN No. } \\
\text { 18/DSN- } \\
\text { MUI/ } \\
\text { IX/2000 }\end{array}$ & $\begin{array}{l}\text { tentang } \\
\text { Pen- } \\
\text { cadan- } \\
\text { gan } \\
\text { Pengha- } \\
\text { pusan } \\
\text { Aktiva } \\
\text { Pro- } \\
\text { duktif } \\
\text { dalam } \\
\text { Lem- } \\
\text { baga } \\
\text { Keuan- } \\
\text { gan } \\
\text { Svari'ah }\end{array}$ \\
\hline 12. & $\begin{array}{l}\text { PBINo. } \\
13 / 23 / \\
\text { PBI/2011 } \\
\text { tentang } \\
\text { Penerapan } \\
\text { Manajemen } \\
\text { Risiko } \\
\text { Bagi Bank } \\
\text { Umum } \\
\text { Syariah dan } \\
\text { Unit Usaha } \\
\text { Syariah. }\end{array}$ & - & - & \\
\hline 13. & $\begin{array}{l}\text { PBINo. } \\
\text { 14/6/2012 } \\
\text { tentang Uji } \\
\text { Kemam- } \\
\text { puan Dan } \\
\text { Kepatutan } \\
\text { (Fit And } \\
\text { Proper } \\
\text { Test) Bank } \\
\text { Syariah dan } \\
\text { Unit Usaha } \\
\text { Syariah. }\end{array}$ & - & - & - \\
\hline 14. & $\begin{array}{l}\text { PBINo. } \\
14 / 17 / 2012 \\
\text { tentang } \\
\text { Kegiatan } \\
\text { Usaha Bank } \\
\text { Berupa } \\
\text { Penitipan } \\
\text { Dengan } \\
\text { Pengelolaan } \\
\text { (Trust) }\end{array}$ & $\begin{array}{l}\text { BAB II } \\
\text { Kegiatan } \\
\text { Trust }\end{array}$ & $\begin{array}{l}\text { Fatwa } \\
\text { DSN No. } \\
01 / \text { DSN- } \\
\text { MUI / } \\
\text { IV/2000 } \\
\text { dan } \\
\text { Fatwa } \\
\text { DSN } \\
\text { No.02/ } \\
\text { DSN- } \\
\text { MUI/ } \\
\text { IV/2000 }\end{array}$ & $\begin{array}{l}\text { tentang } \\
\text { Giro } \\
\text { tentang } \\
\text { Tabun- } \\
\text { gan }\end{array}$ \\
\hline
\end{tabular}

\begin{tabular}{|l|l|l|l|l|}
\hline 15. & PBI No. & Pasal 3, & Fatwa & tentang \\
& $14 / 20 /$ & yang ber- & DSN No. & Pem- \\
& PBI/2012 & bunyi: FP- & 7/DSN- & biayaan \\
& tentang & JPS yang & MUI/ & Mud- \\
& Perubahan & diterima & IV/2000 & harabah \\
Atas Pera- & oleh BPRS & & (Qiradh) \\
turan Bank & menggu- & & \\
& Indonesia & nakan akad & & \\
No. 11/24/ & Mudhara- & & \\
PBI/2009 & bah & & \\
tentang & & & \\
Fasilitas & & & \\
Pendanaan & & & \\
Jangka & & & \\
Pendek & & & \\
Syariah & & & \\
Bagi Bank & & & \\
Umum & & & \\
Syariah. & & & \\
\hline
\end{tabular}

Jika dilihat pada data di atas maka penyerapan fatwa hanya terjadi pada PBI yang berhubungan dengan akad, tidak pada sistem kerja lembaga keuangan. Namun dengan adanya penyerapan fatwa dalam pembentukan PBI ini telah memberikan kesempatan bagi terciptanya regulasi hukum Islam di Indonesia. Hal ini juga menjadikan fungsi KPS dinilai cukup efektif dalam mentransferkan hukum Islam ke dalam hukum positif.

Walaupun pada awalnya pembentukan KPS banyak menuai penolakan karena akan menimbulkan kerancuan antara fungsi DSN dan KPS, namun pada akhirnya KPS menggunakan fungsinya dengan cukup baik dengan berhasilnya Fatwa DSN terserap dalam PBI. Untuk dapat melihat perbedaan dan persamaan antara DSN dan KPS, dapat dilihat pada tabel di bawah ini:

\begin{tabular}{|c|c|c|c|}
\hline No. & Perihal & DSN-MUI & KPS-BI \\
\hline 1. & $\begin{array}{l}\text { Latar } \\
\text { Belakang } \\
\text { pembentu- } \\
\text { kan }\end{array}$ & $\begin{array}{l}\text { Sebagai payung } \\
\text { dari lembaga-lem- } \\
\text { baga organisasi } \\
\text { keagamaan (Islam) } \\
\text { di Indonesia seh- } \\
\text { ingga menganggap } \\
\text { perlu membentuk } \\
\text { satu badan dewan } \\
\text { syariah yang bersi- } \\
\text { fat nasional }\end{array}$ & $\begin{array}{l}\text { Undang-Un- } \\
\text { dang No. } 21 \\
\text { Tahun } 2008 \\
\text { tentang Per- } \\
\text { bankan Syariah: } \\
\text { menindaklanju- } \\
\text { ti implementasi } \\
\text { fatwa Majelis } \\
\text { Ulama Indo- } \\
\text { nesia (MUI) } \\
\text { ke dalam } \\
\text { Peraturan Bank } \\
\text { Indonesia }\end{array}$ \\
\hline
\end{tabular}




\begin{tabular}{|c|c|c|c|}
\hline 2. & Tugas & $\begin{array}{l}\text { 1.Menumbuh- } \\
\text { kembangkan } \\
\text { penerapan } \\
\text { nilai-nilai syariah } \\
\text { dalam kegiatan } \\
\text { perekonomian } \\
\text { pada umumnya } \\
\text { dan keuangan } \\
\text { pada khususnya. } \\
\text { 2.Mengeluarkan } \\
\text { fatwa atas } \\
\text { jenis-jenis kegia- } \\
\text { tan keuangan. } \\
\text { 3.Mengeluarkan } \\
\text { fatwa atas } \\
\text { produk dan } \\
\text { jasa keuangan } \\
\text { syariah. } \\
\text { 4.Mengawasi } \\
\text { penerapan fatwa } \\
\text { yang telah dikel- } \\
\text { uarkan. }\end{array}$ & $\begin{array}{l}\text { Membantu } \\
\text { Bank Indonesia } \\
\text { dalam : } \\
\text { (1) menafsirkan } \\
\text { fatwa MUI } \\
\text { yang terkait } \\
\text { dengan per- } \\
\text { bankan syariah. } \\
\text { (2) memberikan } \\
\text { masukan dalam } \\
\text { rangka imple- } \\
\text { mentasi fatwa } \\
\text { MUI kedalam } \\
\text { PBI. } \\
\text { (3) melakukan } \\
\text { pengembangan } \\
\text { industri per- } \\
\text { bankan syariah. }\end{array}$ \\
\hline 3. & $\begin{array}{l}\text { Bertanggu- } \\
\text { ng jawab } \\
\text { kepada }\end{array}$ & $\begin{array}{l}\text { Majelis Ulama } \\
\text { Indonesia }\end{array}$ & Bank Indonesia \\
\hline 4. & Anggota & $\begin{array}{l}\text { Keanggotaan } \\
\text { DSN terdiri dari } \\
\text { Pengurus Pleno } \\
\text { (56 Anggota) dan } \\
\text { Badan Pelaksana } \\
\text { Harian (17 orang } \\
\text { anggota). Ketua } \\
\text { DSN-MUI dijabat } \\
\text { Ex Officio Ketua } \\
\text { Umum MUI dan } \\
\text { sekretaris DSN- } \\
\text { MUI dijabat Ex } \\
\text { Officio Sekretaris } \\
\text { Umum MUI. Ada- } \\
\text { pun keanggotaan } \\
\text { DSN diambil dari } \\
\text { pengurus MUI, } \\
\text { Komisi Fatwa } \\
\text { MUI, Ormas } \\
\text { Islam, Perguruan } \\
\text { Tinggi Islam, } \\
\text { Pesantren dan } \\
\text { para praktisi pere- } \\
\text { konomian syariah } \\
\text { yang memenuhi } \\
\text { kriteria dan diusul- } \\
\text { kan oleh Badan } \\
\text { Pelaksana Harian } \\
\text { DSN yang mana } \\
\text { keanggotaan baru } \\
\text { DSN ditetapkan } \\
\text { oleh Rapat Pleno } \\
\text { DSN-MUI }\end{array}$ & $\begin{array}{l}\text { Perwakilan dari } \\
\text { Bank Indone- } \\
\text { sia, Departe- } \\
\text { men Agama } \\
\text { dan unsur } \\
\text { masyarakat } \\
\text { dengan } \\
\text { komposisi be- } \\
\text { rimbang yang } \\
\text { ditetapkan oleh } \\
\text { Bank Indonesia } \\
\text { dan memenuhi } \\
\text { persyaratan } \\
\text { integritas dan } \\
\text { kompetensi, } \\
\text { dengan jumlah } \\
\text { anggota paling } \\
\text { banyak } 11 \text { (se- } \\
\text { belas) orang }\end{array}$ \\
\hline
\end{tabular}

\begin{tabular}{|c|c|c|c|}
\hline 5. & Masa Bakti & $\begin{array}{l}\text { Keanggotaan } \\
\text { DSN ditunjuk } \\
\text { dan diangkat oleh } \\
\text { MUI untuk masa } \\
\text { bakti } 4 \text { tahun }\end{array}$ & $\begin{array}{l}\text { Masa jabatan } \\
\text { anggota } \\
\text { Komite Per- } \\
\text { bankan Syariah } \\
\text { adalah } 2 \text { (dua) } \\
\text { tahun, dan } \\
\text { dapat } \\
\text { diperpanjang } \\
\text { paling banyak } 2 \\
\text { (dua) kali masa } \\
\text { jabatan. }\end{array}$ \\
\hline 6. & $\begin{array}{l}\text { Pem- } \\
\text { biayaan }\end{array}$ & $\begin{array}{l}\text { a.DSN mem- } \\
\text { peroleh dana } \\
\text { operasional dari } \\
\text { bantuan pemer- } \\
\text { intah (Depkeu), } \\
\text { Bank Indonesia, } \\
\text { dan sumbangan } \\
\text { masyarakat. } \\
\text { b.DSN meneri- } \\
\text { ma dana iuran } \\
\text { bulanan dari } \\
\text { setiap lembaga } \\
\text { keuangan syari- } \\
\text { ah yang ada. } \\
\text { c.DSN memper- } \\
\text { tanggung-jawab- } \\
\text { kan keuangan } \\
\text { atau sumbangan } \\
\text { tersebut kepada } \\
\text { MUI. }\end{array}$ & $\begin{array}{l}\text { Anggaran dan } \\
\text { biaya-biaya } \\
\text { sehubungan } \\
\text { pelaksanaan } \\
\text { tugas Komite } \\
\text { Perbankan } \\
\text { Syariah menjadi } \\
\text { beban anggaran } \\
\text { Bank Indonesia }\end{array}$ \\
\hline 7. & $\begin{array}{l}\text { Mekanisme } \\
\text { Kerja }\end{array}$ & $\begin{array}{l}\text { a.DSN mensahkan } \\
\text { rancangan fatwa } \\
\text { yang diusulkan } \\
\text { oleh Badan Pen- } \\
\text { gawas Harian } \\
\text { DSN. } \\
\text { b.DSN melakukan } \\
\text { rapat pleno } \\
\text { paling tidak } \\
\text { satu kali dalam } \\
\text { tiga bulan, atau } \\
\text { bilamana diper- } \\
\text { lukan. } \\
\text { c.Setiap tahunnya } \\
\text { membuat suatu } \\
\text { pernyataan yang } \\
\text { dimuat dalam } \\
\text { laporan tahunan } \\
\text { bahwa lembaga } \\
\text { keuangan } \\
\text { syariah yang } \\
\text { bersangkutan } \\
\text { telah atau tidak } \\
\text { memenuhi se- } \\
\text { genap ketentuan } \\
\text { syariah sesuai } \\
\text { dengan fatwa } \\
\text { yang dikeluar- } \\
\text { kan oleh DSN }\end{array}$ & $\begin{array}{l}\text { a.Fatwa } \\
\text { DSN akan } \\
\text { ditafsirkan } \\
\text { dan dalam } \\
\text { pengambilan } \\
\text { keputu- } \\
\text { san akan } \\
\text { dilaksanakan } \\
\text { pada Rapat } \\
\text { Komite } \\
\text { b.Hasil } \\
\text { pelaksanaan } \\
\text { tugas komite } \\
\text { tersebut nan- } \\
\text { tinya akan } \\
\text { disampaikan } \\
\text { kepada } \\
\text { DPbS Bank } \\
\text { Indonesia } \\
\text { dalam bentuk } \\
\text { Rekomendasi } \\
\text { Komite. } \\
\text { c.rekomendasi } \\
\text { Komite } \\
\text { tersebut } \\
\text { menjadi } \\
\text { bahan bagi } \\
\text { DPbS dalam } \\
\text { merumuskan } \\
\text { draft PBI }\end{array}$ \\
\hline
\end{tabular}


Dalam penjelasan mengenai Mekanisme KPS, dijelaskan bahwa hasil pelaksanaan tugas komite (penafsiran terhadap fatwa DSN) tersebut nantinya akan disampaikan kepada DPbS Bank Indonesia dalam bentuk Rekomendasi Komite. Terkait hubungan antara DSN-MUI, KPS dan DPbS, bahwa dalam pembentukan PBI nantinya DPbS Bank Indonesia akan melibatkan KPS yang di dalamnya terdapat representasi dari DSN-MUI oleh karena itu DSN-MUI secara kelembagaan belum tentu dilibatkan. Namun, DPbS dapat melibatkan DSN-MUI apabila memang perlu. Intinya KPS nantinya akn melakukan harmonisasi fatwa agar compatible bagi praktik perbankan. DPbS dalam membuat draft PBI juga tetap melibatkan unsur DSN-MUI. Oleh karenanya, PBI yang materi muatannya berasal dari fatwa DSN-MUI tetap sesuai dengan maksud pembuat fatwa, namun aplikatif diterapkan oleh Bank Syariah dan Unit Usaha Syariah dalam operasional kegiatan usahanya.

\section{Penutup}

Dari paparan data analisis tersebut, maka dapat dismpulkan bahwa:

1. Fatwa MUI (DSN-MUI) jika dilihat dalam kerangka hukum positif maka fatwa tersebut tidak mempunyai kekuatan hukum mengikat. Akan tetapi fatwa memiliki kekuatan hukum yang mengikat apabila fatwa tersebut diperkuat dengan instrumeninstrumen negara yang mempunyai alat legitimasi, seperti Undang-undang, Peraturan Pemerintah (PP), Peraturan Bank Indonesia (PBI), atau sejenisnya. Salah satu dasar hukum yang dapat dipakai dalam proses transformasi agar Fatwa DSN-MUI dapat menjadi sebuah hukum positif adalah UU No. 21 Tahun 2008 tentang Perbankan Syariah yang mengharuskan Bank Indonesia membentuk Komite Perbankan Syariah yang bertugas menafsirkan fatwa DSN-MUI (tugas KPS sebagaimana dalam Peraturan Bank Indonesia Nomor 10/32/PBI/2008 tentang Komite Perbankan Syariah) agar dapat dituangkan menjadi PBI. Oleh sebab itu ketika sebuah fatwa telah ditransformasi ke dalam PBI maka Bank Indonesia dapat memberikan sanksi bagi bank syariah atau unit usaha syariah yang tidak melaksanakan ketentuan sesuai dengan PBI tersebut.
2. Transformasi Fatwa DSN-MUI merupakan sebuah keharusan dan dianggap urgent ketika sebuah hukum Islam (dalam hal ini Fatwa DSN-MUI) ingin memiliki kekuatan hukum mengikat dalam hukum positif. Hal ini disebabkan Bank Indonesia tidak bisa memberikan sanksi bagi bank syariah atau unit usaha syariah yang tidak mengikuti fatwa. Oleh sebab itu solusi yang ditempuh agar fatwa menjadi mengikat adalah melalui transformasi fatwa DSN ke dalam PBI. Adapun proses transformasi tersebut dipengaruhi oleh KPS sebagai pemberi rekomendasi terhadap fatwa DSN. Ketika fatwa ditransformasi ke dalam hukum positif ia telah mengalami perubahan wujud dan fungsi dalam konteks sistem hukum nasional. Fatwa telah terintegrasi dengan norma lain, yang telah berubah bentuk menjadi hukum positif. Bahkan dalam hal tertentu mengalami perubahan makna, baik dalam arti perluasan makna maupun penyempitan makna. Hal ini dapat dilihat pada masa sebelum UU No. 21 Tahun 2008 tentang Perbankan Syariah disahkan Fatwa DSN secara jelas dimuat sebagai bahan pertimbangan hukum oleh BI walaupun disebutkan hanya dalam Kodifikasi Produk Keuangan Syariah. Sedangkan setelah UU Perbankan Syariah disahkan fatwa-fatwa tersebut hanya dapat dilihat secara tersirat dalam PBI karena tidak ada penjelasan secara eksplisit yang menyatakan fatwa tertentu yang digunakan.

\section{DAFTAR PUSTAKA}

Departemen Agama RI. 1412 H. Al Quran dan Terjemahannya (AlQur'an wa Tarjamah Ma'nibi ila Al Lughah al Indonesiyyah), Makkah: Khadim Al Haramain Asy Syarifain Al Malik Fadh bin Abdul Aziz As Su'udi Ath Thaba'ah al Mushah Asy Syarif.

Departemen Pendidikan Nasional. 2005. Kamus Besar Bahasa Indonesia. Jakarta: Balai Pustaka. Ed. ke-3.

Kamil, Ahmad dan M. Fauzan. 2007. Kitab Undangundang Hukum Perbankan dan Ekonomi Syariah. Jakarta: Kencana Prenada Media Group. 
Komisi Pemberdayaan Ekonomi Umat Majelis Ulama Indonesia Provinsi Kalimantan Selatan. 2012. Kumpulan Fatwa Majelis Ulama Indonesia (DSN-MUI) tentang Ekonomi Islam. Banjarmasin: MUI Kal-Sel.

Manan, Abdul. 2007. Beberapa Masalab Hukum dalam Praktek Ekonomi Syariah, Makalah Diklat Calon Hakim Angkatan-2 di Banten.

, Abdul. Penyelesaian Sengketa Ekonomi Syariab; Sebuah Kewenangan Baru Peradilan Agam. Sebuah makalah.

Mubaraok, Jaih. 2002. Metodologi Ijtihad Hukum Islam. Yogyakarta: UII Press.

Muslich, Ahmad Wardi. 2010. Fiqh Muamalat. Jakarta: Amzah.

Nasikhin, Muh. 2010. Perbankan Syariah \& Sistem Penyelesaian Sengketanya, Semarang: Fatawa publishing.

Nasution, M. 2000. Metode Penelitian Kualitatif. Bandung: PT Remaja Rosydakarya.

Ritonga, A. Rahman. 2000. Ensiklopedi Hukum Islam, cet. 4, Jakarta: PT. Ichtiar Baru van Hoeve.

Sabiq, Sayyid. 1993. Fiqh al Sunnah, di-Indonesia oleh Mudzakir AS, dengan judul Fikih Sunnah, Jilid XIV. Bandung: Alma'arif.

Sugiono, Muhammad Kedudukan Fatwa dalam Syariat Islam, ditulis pada tanggal 30 Januari 2009, $\% 20$ S2 $\% 202 /$ Kumpulan $\% 20 U U, \% 20$ Fatwa $\% 20$ dan $\% 20$ PBI/Kedudukan $\% 20$ Fatwa $\% 20$ dalam $\% 20$ Syariat $\% 20$ Islam $\% 20$ $\% \mathrm{C} 2 \% \mathrm{AB} \% 20$ muhammadsugiono, diakses pada tanggal 20 September 2010.

Sumitro, Warkum. 2004. Asas-Asas Perbankan Islam \& Lembaga-lembaga Terkait (BAMUI, Takaful dan Pasar Modal Syariah di Indonesia). Jakarta: Raja Grafindo Persada.

1996. Asas-asas Perbankan Islam dan Lembaga-lembaga Terkait (BMUI \& Takaful) di Indonesia, Jakarta: Rajawali Press.

Tim. 2006. Ensiklopedi Hukum Islam. Jakarta: PT Ichtiar Baru Van Hoeve. Cet. ke-7.

Tim. 2007. Menjawab Keraguan Umat Islam Tehadap Bank Syariah. Jakarta: Pusat Komunikasi Ekonomi Syariah.

Usman, Rachmadi Aspek-Aspek. Hukum Perbankan Islam di Indonesia, (Bandung:PT. Citra Aditya Bakti), 2002, hal. 105. 
